\title{
Climate change adaptation in practice: people's responses to tidal flooding in Semarang, Indonesia
}

\author{
D. Harwitasari ${ }^{1}$ and J.A. van Ast ${ }^{2}$ \\ 1 Government of Indonesia, Public Works, Semarang, Indonesia \\ 2 Erasmus University Rotterdam, Dpt Public Administration, M7-09, P.O. Box 1738, 3000 Dr Rotterdam, the Netherlands
}

\section{Correspondence}

Jacko A. van Ast, Erasmus University Rotterdam, Public Administration.

Email: vanast@fsw.eur.nl

DOI:10.1111/j.1753-318X.2011.01104.x

Key words

flood adaptation, climate change, integrated water management, coastal lowlands.

\begin{abstract}
In many places in the world the effects of common floods are increased by climate change. In the area around the Indonesian city of Semarang, the number and effects of tidal flooding are becoming more and more severe. We found that the inhabitants used different strategies against the impact of flooding. In both the existing and the predicted flood prone areas, most people appear not to intend to leave the area, even when the floods become everyday routine. People are connected to their dwellings in a way that abandoning is not a realistic scenario. This study provides relevant information about the way people in the affected areas perceive flood risks and adaptation opportunities. Governmental policymakers and urban planners could base their strategies and actions on this information.
\end{abstract}

\section{Introduction}

Floods occur in small and large river basins, in estuaries and by the coasts of seas and oceans. Many of the various causes, such as rainfall, storm surge, tidal movement, tsunami, rising ground water level, dam break or sewer overflow are accelerated by climate change [Penning-Rowsell and Peerbolte, 1994; Intergovernmental Panel on Climate Change (IPCC) 2007]. The following paper focuses on an example of the low coastal zones, which encompass approximately $10 \%$ of the world's population and $13 \%$ of world's urban population (McGranahan et al., 2007).

Even though governments are formulating policies, there is currently limited information available about the behaviour of the concerned populations. A central question to be addressed is how the inhabitants of these areas deal with the increasing threat of flooding. Do they already have experience with the negative effects? What will they do if the sea continues to rise? Will they adapt to higher sea water levels or do they intend to leave their homes? The answers to these questions regarding future uncertainties are of utmost importance for governments that seriously want to formulate flood reduction strategies.

Within this case study, the example of tidal flooding in Semarang, along the coastline of the Indonesian island of Java, has been studied. The flooding here is usually not high enough to endanger human lives; but it occurs frequently and is very disturbing. The case is about the rise in sea level combined with land subsidence and gives an insight in the struggle of an urbanizing area with climate change.

\section{Tidal flood, climate change and land subsidence}

Most tidal flooding occurs in coastal areas that are - in geological terms - relatively recently created by sedimentation. In historical times, people only started to live in these areas when flooding was reduced to rare occasions. More recently, however, population explosion, urbanization and high land prices have enlarged the pressure on floodvulnerable areas. Many floods in the low-elevation coastal zones, according to Doornkamp (1998) are the result of a combination of high tides and high flows of inland rivers. Marfai (2004) defines 'tidal flood' as 'coastal flooding when caused by high tide'. Marfai and King (2007a, b) refer to tidal floods as the combination of high tide, wave action and accelerated sea level rise. This last factor, due to climate change, can increase the frequency of tidal flooding considerably. In Semarang, the floods are mainly related to tidal movement in low-lying areas, strengthened by the rise in sea level and land subsidence.

Global estimates of the IPCC(2007) predict that the sea level in Indonesia will rise $100 \mathrm{~cm}$ due to increased sea water temperature from $1.3{ }^{\circ} \mathrm{C}$ to $4.6{ }^{\circ} \mathrm{C}$ in the year 2100 . It will clearly deepen the stress of coastal areas, causing floods, erosion of the shores and destruction of costal structure (Nicholls et al., 1999; Nicholls, 2004; Munasinghe and Swart, 
2005; Snoussi et al., 2008) and will enhance a decrease in water quality and seawater intrusion into the fresh water sources.

Another important reason for the increase in flood risks in many coastal areas is land subsidence (Syvitski et al., 2009). According to Sutanta et al. (2005), land subsidence occurs when the elevation of the land is lowered from its previous position, with respect to a fixed height reference system. This is fundamentally related to the lack of compensating sedimentation, which is due to the protection of human settlements from the water. Furthermore, ground water extraction, in combination with the soil type, is a major accelerating human-induced factor.

In Semarang, the tidal flood is caused by a combination of a rise in sea levels and land subsidence. Land subsidence in Semarang is mainly caused by extraction of underground water resources, the load of constructions and the industrialization patterns on reclaimed land (Doornkamp, 1998). In Semarang, an accelerated rise in sea level and land subsidence together result in a fast broadening of the floodprone areas towards the outer coastal areas (Wibowo, 2006). Following up earlier studies including Dewi (2007) and Marfai et al. (2008), the study was focused on the responses to the threat of flooding in the coastal zone of Semarang.

\section{Responses to tidal flooding}

On a high-level scale, Nicholls (2002) mentions four actions to reduce the impact of flooding in coastal areas:

1. Mitigate climate change by reducing greenhouse gas emissions.

2. Avoid human enhancement of areas vulnerable to subsidence.

3. Upgrade protection against flooding.

4. Control the growth of exposure by encouraging the expanding coastal population to avoid location to coastal floodplains.

At the local scale of an urban area, governments usually concentrate on action types two and three; these are adaption measurements. They can have a nontechnical and a technical character (Klein et al., 2001).

In the context of climate change, adaptation is a process where individuals and communities seek to reduce vulnerability or enhance resilience in response to observed and expected changes due to climate change (McCarthy et al., 2001; Adger et al., 2007). On the basis of the conclusions of the IPCC (2007), Munasinghe and Swart (2005) consider adaptation as a necessary strategy throughout all the stages and scales to complete climate change mitigation efforts. Smit and Pilifosofa (2001) stress that human system adaptation to climate change can be motivated by both private and public interests. In practice, adaptations tend to be on-going processes, reflecting many factors or stresses, rather than specific measures that address climate change. Not all of them support the creation of climate resilient cities (Prasad et al., 2009).

Adaptation measures can be reactive, responding to the impacts as they occur, and they can be proactive, implemented in advance to reduce future climate risk and vulnerability (Smit and Pilifosofa, 2001). Adaptation can also be differentiated into autonomous adaptation and planned adaptation. Autonomous adaptation refers to unmanaged actions, without any interventions from government, whereas planned adaptation refers to adaptation as a part of climate change response strategy by governments (Munasinghe and Swart, 2005). Autonomous adaptation usually is reactive. Planned adaptation can be either reactive or proactive. Autonomous adaptation measures are based on initiatives from the private sector, mostly triggered by market and welfare changes.

According to Pittock and Jones (2000), planned adaptation consists of nonphysical measures: writing, talking, educating and awareness raising together have to lead eventually to real actions in the field. These actions are part of the policy domain as a public agency or government is always involved. Regarding physical adaptation, Munasinghe and Swart (2005) consider three physical strategies for human settlements:

1. Protection of the land from the sea by construction of structures such as seawalls and beach nourishment.

2. Accommodation to the higher water levels such as elevation of buildings and growing salt-tolerant or flood-tolerant crops.

3. Retreat: abandoning of the endangered coastal areas.

Table 1 summarizes the typology of adaptation measures.

According to Satterthwaite et al. (2007), resources such as income, property and knowledge increase people's capacity to avoid the hazard or to adapt to risks. Households or neighbourhoods with higher income levels are better in managing vulnerabilities and impacts of tidal flood. The income level enhances the willingness and the ability to execute adaptation measures. The same applies to education level: the higher the education level, the more knowledge people have about dealing with risks, such as - in this case -

Table 1 Typology of selected measures

\begin{tabular}{lll}
\hline & \multicolumn{2}{c}{ Adaptation measures } \\
\hline Response? & Ex post: reactive & Ex ante: proactive \\
Initiative? & Private: autonomous & Government: planned \\
Type of action? & Execution, physical: & Policy, nonphysical: \\
& Protection & Writing \\
& Accommodation & Talking \\
& Retreat & Educating \\
& & Awareness raising \\
\hline
\end{tabular}




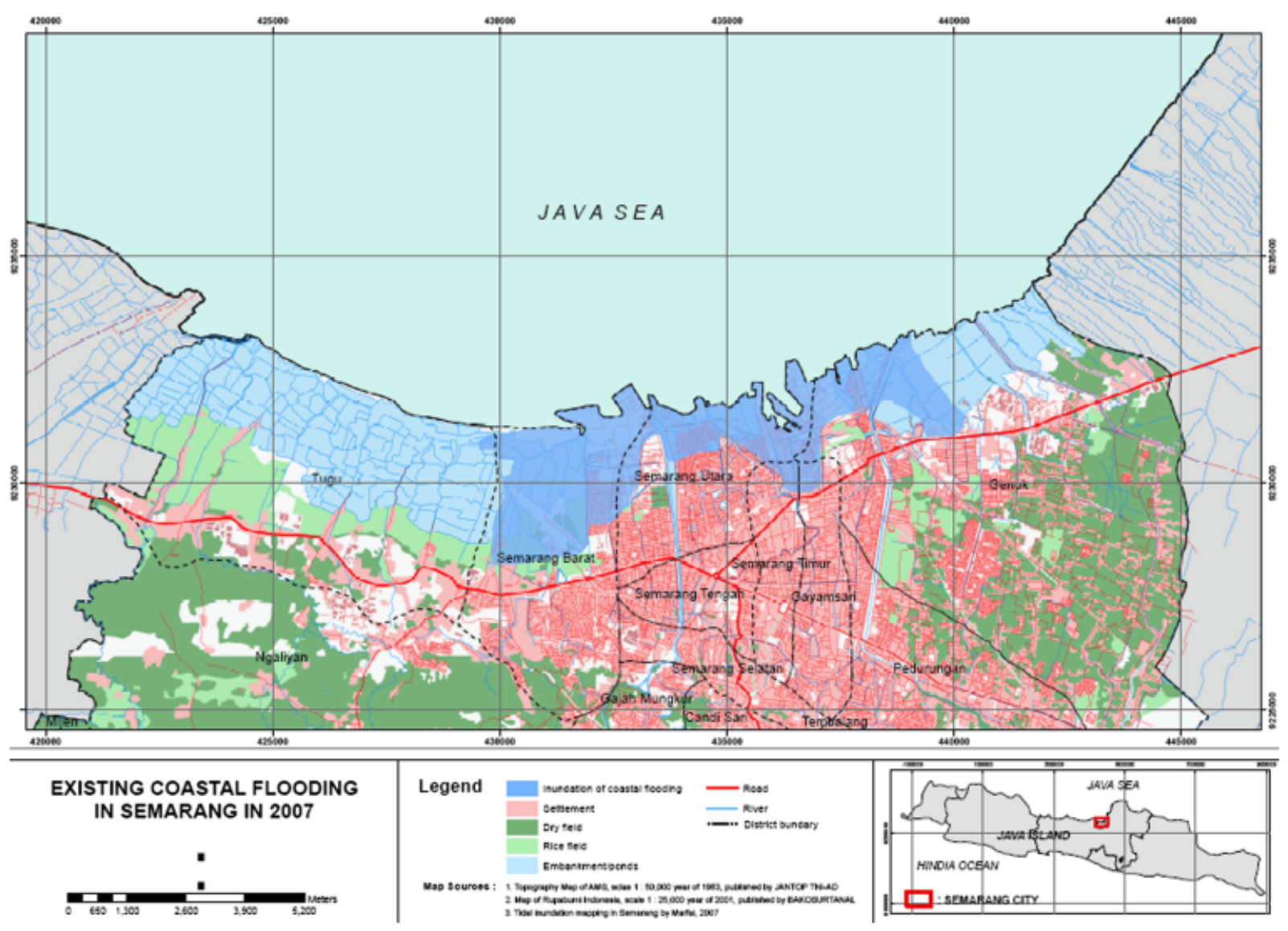

Figure 1 Periodically inundated areas of Semarang (Semarang Municipality, 2009).

tidal floods. House ownership is another important factor. Inhabitants living in a self-owned property generally will be stronger protected from hazards. People who live in their own house are more eager to start activities against the tidal flood than people living in rented accommodation.

\section{Tidal flooding in Semarang}

In this case study, the coping strategies of present inhabitants of the flood-vulnerable area of Semarang were identified. Semarang is the capital city the Central Java Province, located in the northern part of Java Island. It has an area of $400 \mathrm{~km}^{2}$ and approximately 1.5 million inhabitants (Statistic Bureau Semarang, 2006). Semarang is the fourth largest city in Indonesia. In the South, the city is built on a hilly area. The low-lying area of $121 \mathrm{~km}^{2}$ is located in the North, with elevations from 0 to $25 \mathrm{~m}$ above average sea level. For the last 20 years, around 1,200 ha of low-lying swamps and fields have been urbanized in Semarang municipality (Wibowo, 2006). High urbanization and high population pressure have changed catchment areas, embankments, swamps and fields into industrial and settlement areas.
Semarang faces three types of flooding: local inundation that is mainly caused by rainfall, river flooding due to water overflow from the hinterland, and tidal flood, caused by high tide from the sea (Marfai and King, 2007a, b). Local flooding and river flood occur during the rainy season on the lower part of the catchments when the rainfall in the catchment area exceeds the capacity of stream channel and drainage ditches. Tidal flood occurs when the sea level rises to a critical height above the coastal lands due to tidal elevation. Tidal floods occur daily, depending on the tidal oscillation combined with the drainage system.

Areas with an elevation of $<1.26 \mathrm{~m}$ above average sea level are vulnerable to tidal floods, which means that the total periodically inundated area in 2007 was about 1,970 ha. These areas have been mapped in Figure 1.

Between 1985 and 1998, the sea level rose $58.2 \mathrm{~cm}$ in Semarang, bringing the average rate of rise in sea level during this period to $4.47 \mathrm{~cm} /$ year (Ministry of Fishery and Marine Affairs, 2009). During the years 2003-2008, however, the rise in sea level increased to $37.2 \mathrm{~cm}$; an average rate of $7.43 \mathrm{~cm} /$ year. Besides the rise in sea level, land subsidence in the area is also accelerating. The deposits in the area, such as marine 


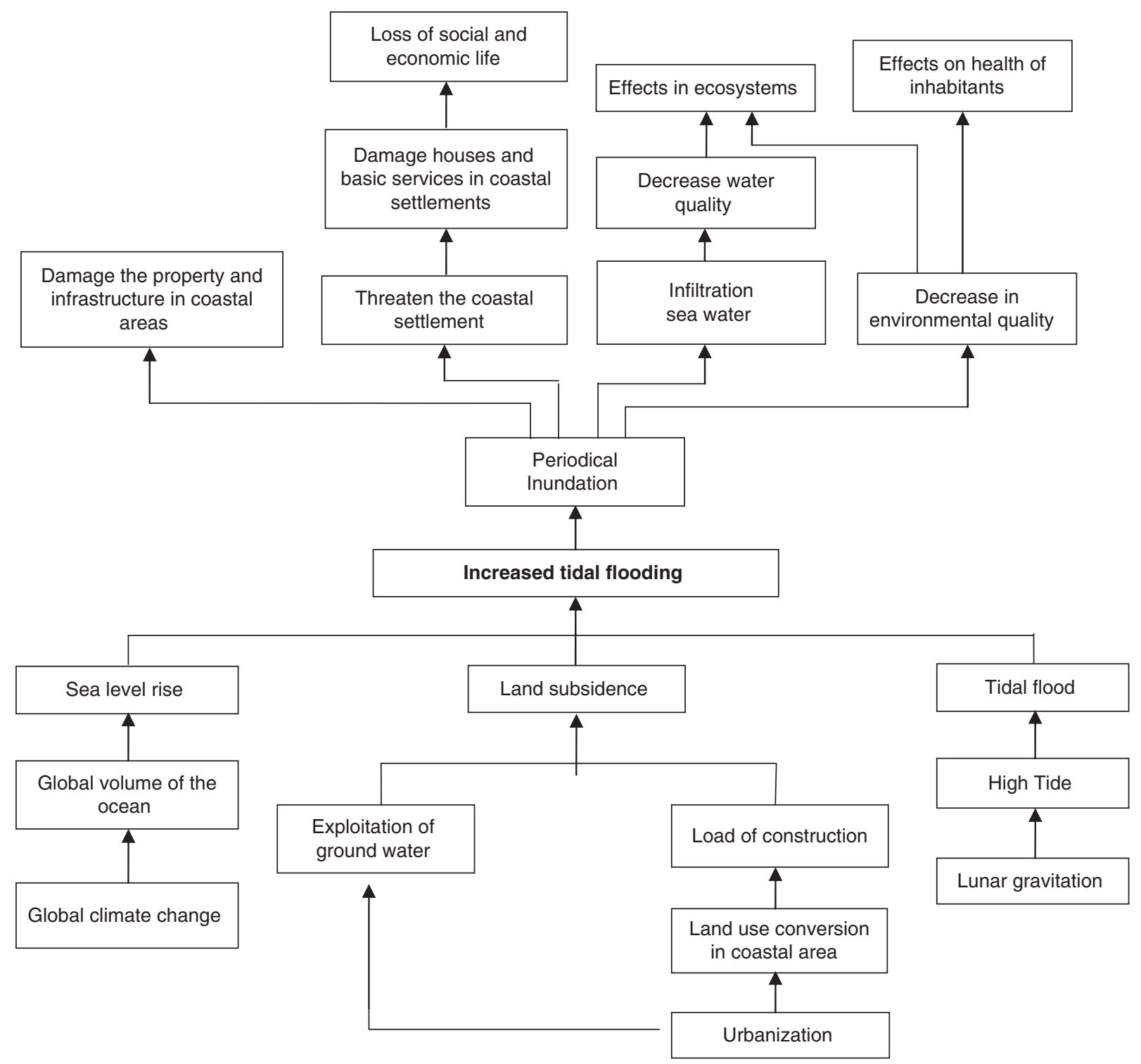

Figure 2 Problem tree tidal flooding in Semarang.

and alluvial sediments, are susceptible to land subsidence and are strengthened by an extreme groundwater withdrawal (Marfai and King, 2007a, b). Exploitation of ground water in Semarang for drinking water was about $0.43 \times 10^{6} \mathrm{~m}^{3} /$ year in 1990 and increased to $35.64 \times 10^{6} \mathrm{~m}^{3} /$ year in 1998 [Japan International Cooperation Agency (JICA), 2003]. This is roughly in line with the urbanization rate and population growth. The maximum observed rate of land subsidence in the lower areas of Semarang is about $16 \mathrm{~cm} /$ year, the minimum about $1 \mathrm{~cm} /$ year and the average is approximately $6 \mathrm{~cm} /$ year (Public Works Agency of Semarang, 2000).

In accordance with Marfai et al. (2008) the authorities that have been interviewed have declared that coastal flooding has been a rising problem in Semarang coastal areas for many years. Most urban infrastructures located in coastal areas such as the roads, the airport, the central station and the harbour are regularly damaged by rising water. Settlements along the coastal area have also been affected. Many houses and small and medium business enterprises have been damaged, causing large social and economical impacts. It also has repercussions on the environment of the settlement areas, for example the infiltration of sea water into the ground water.

The interrelation of causes and effects of tidal flood in Semarang can be found in the problem tree (Figure 2).

\section{Flood responses in Semarang}

In order to obtain insight in current and future adaptation responses to tidal flooding, primary data were collected in 


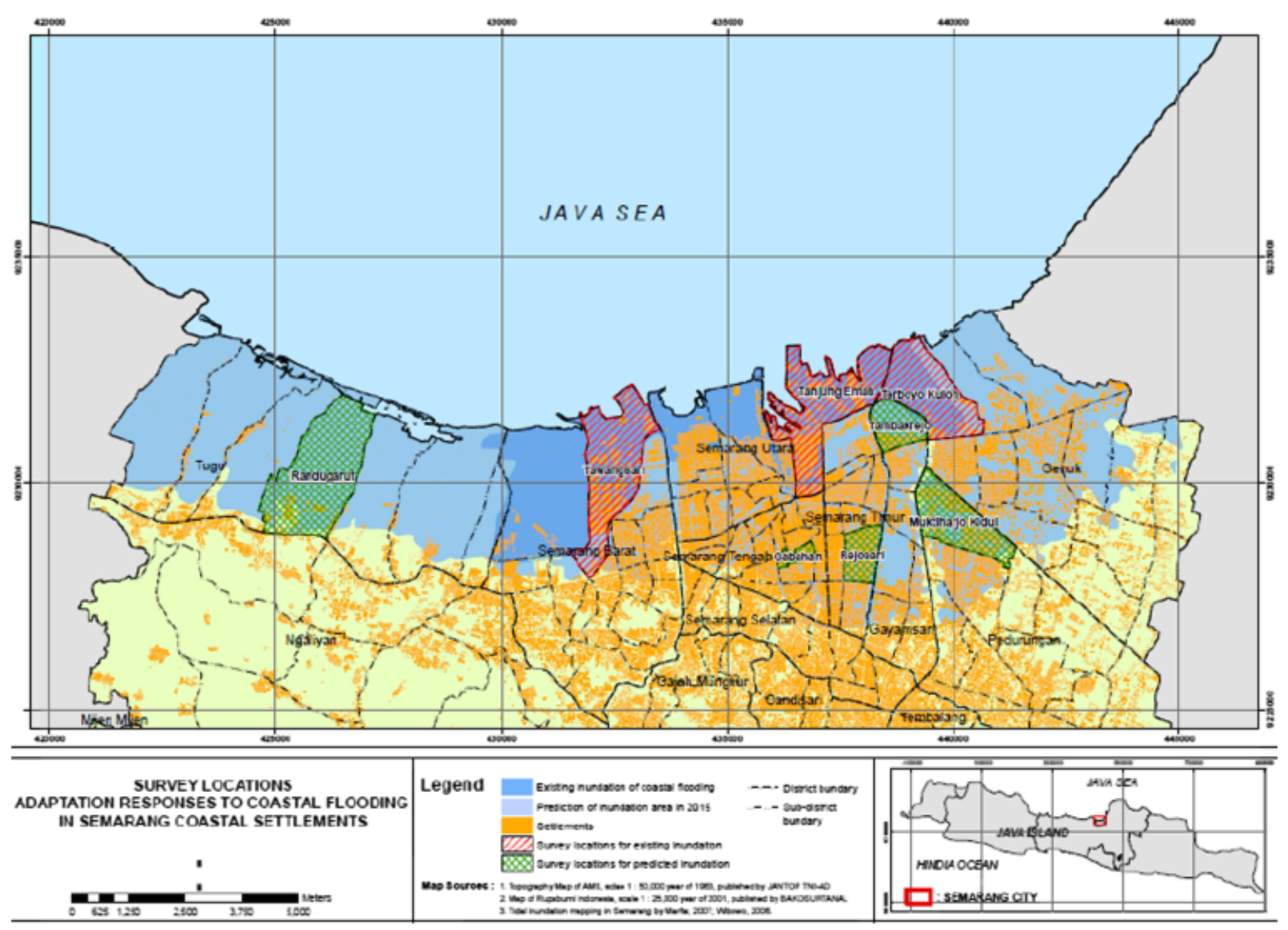

Figure 3 Selected tidal flood areas for interviews (Semarang Municipality, 2009).

Semarang in the second half of 2009 through observational study, questionnaires and semistructured interviews. A survey was conducted with 110 inhabitants, of which 60 questionnaires were administered to the respondents living in presently inundated areas, and 50 questionnaires in districts of the predicted inundated areas (Figure 3). The present six subdistricts that are regularly inundated, have a population of approximately 70000 inhabitants (Statistic Bureau Semarang, 2006). The subdistricts are named Tambakharjo, Panggung lor, Bandarharjo, Tawangsari, Tanjung Mas and Terboyo Kulon. In all of the three last mentioned sub districts, 20 respondents were randomly interviewed. The investigated areas that are predicted to be inundated are in the following five subdistricts: Semarang Timur, Semarang Tengah, Genuk, Gayamsari, Pedurungan and Tugu. In each of these five subdistricts, 10 inhabitants were randomly interviewed.

Additional information was collected from semistructured interviews with the Semarang Water Management Agency, the Semarang Planning and Development Board, the Semarang City Planning Agency, the Head of Semarang Barat District and the Head of Tanjung Mas Subdistrict (one of the presently inundated areas). Comple- mentary secondary data were collected from the local government (Semarang Public Works Agency, Semarang City Planning Agency and Semarang Planning and Development Board) and from the Semarang Statistical Office.

\section{Experience with tidal flooding}

The survey initially wished to clarify whether the floods were actually experienced by the inhabitants. In the regularly inundated districts, around $25 \%$ of the respondents replied to have been affected by the tidal floods for more than 8 years and more than $50 \%$ of the inhabitants had been affected by the tidal floods up to 4 years (Figure 4 ).

Figure 5 shows the number of floods that have been experienced by the inhabitants. The majority of respondents claim to be affected by floods about four to nine times a month. Approximately $10 \%$ of the respondents experience flooding on a daily basis.

In the case of flooding, inundation endures from 1 day to more than 5 days. Figure 6 shows that the majority of the respondents experience flood inundation for only 1 day, 


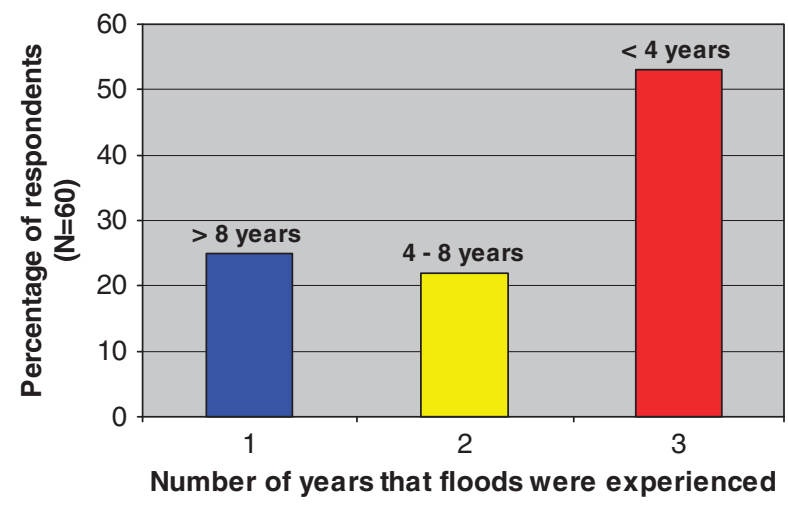

Figure 4 Times that flood was experienced.

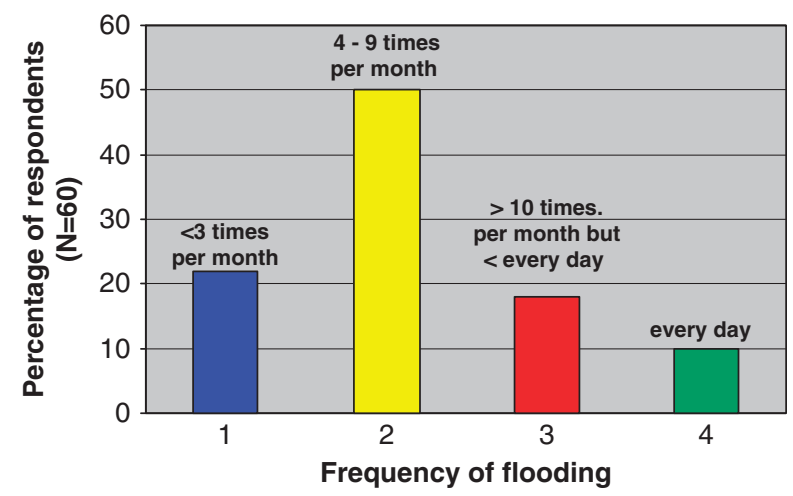

Figure 5 Average number of floods experienced.

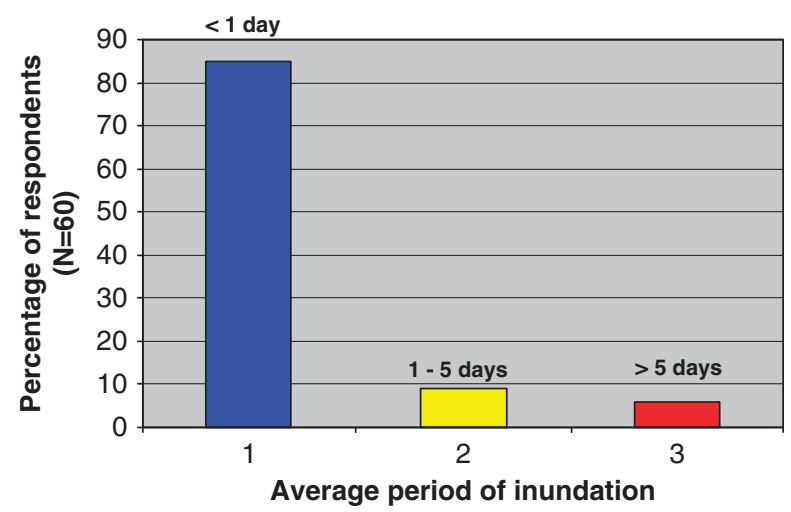

Figure 6 Average period in days of flood duration.

while $6 \%$ of the respondents are affected by the flooding for a period of more than 5 days.

Figure 7 shows that there is a great water-level variation between the different flood occasions. The most common flood depth is less than half a metre and the worst is over $1 \mathrm{~m}$ in depth.

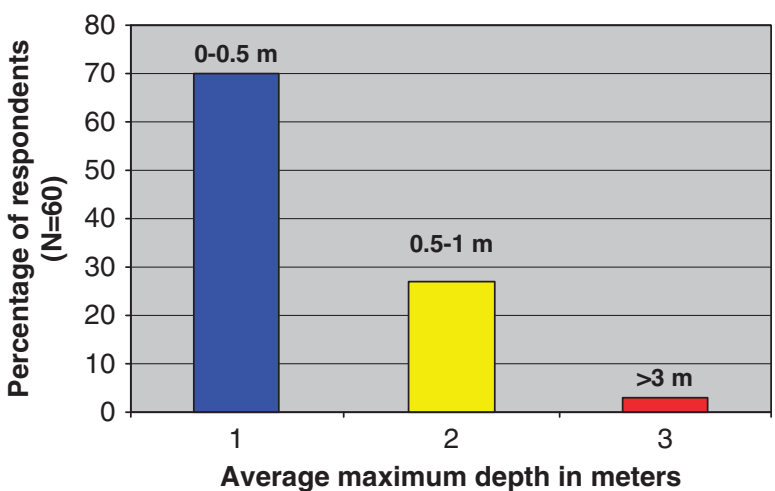

Figure 7 Average height in metres of experienced floods.

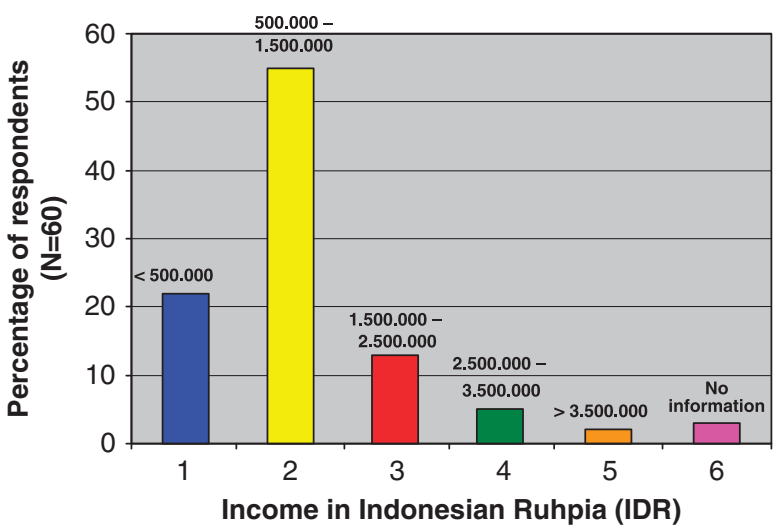

Figure 8 Income level in IDR of respondents.

It is clear that tidal flooding is experienced as a reality by the respondents. The following section of this paper explores the ways in which people deal with this reality.

\section{Adaptation measures}

Variability in characteristics of affected people determines their types of adaptation measures. In order to predict flood adaption capacity, the three mentioned indicators of Satterthwaite et al. (2007) were used: income level, property ownership and knowledge level. In the survey, most of the respondents had a lower middle class income for Indonesian standards, between IDR 500000 and IDR 1500 000/month $(€ 36-€ 100$ in 2009) (Figure 8). Average monthly salary in Indonesia in 2009 was IDR $2025000 /$ month (Statistic Bureau Indonesia, 2010).

The respondents had a relatively high level of education. Most of respondents graduated from high school, and $29 \%$ had a university or college education. Only $3 \%$ of the respondents were uneducated (Figure 9).

The majority of households own their property. Only few respondents rent houses or stay in relative's houses (Figure 10). 
In Semarang, most of the inhabitants in the (tidal) flood-prone areas fulfil the indicators for a high adaptation capacity. They have an income, they are educated and they own their own property.

The next question that was addressed was about which preventative measures these inhabitants took? From the 60 respondents, 53, or $88 \%$, have taken certain adaptation measures regarding their house (Table 2). Most people have been elevating their houses and raising their floor levels in order to make their houses flood proof.

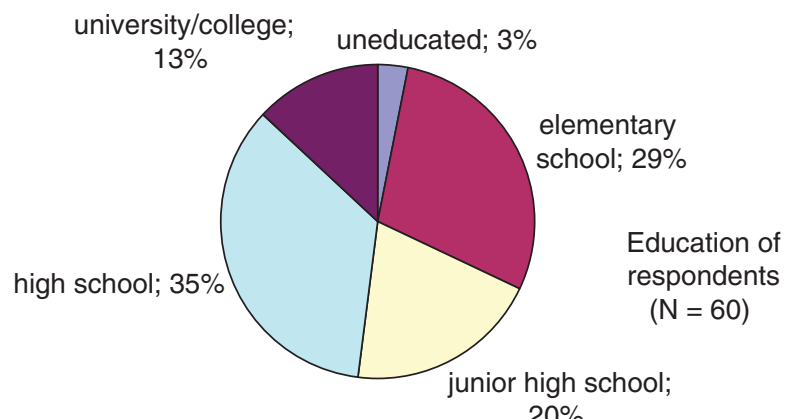

Figure 9 Education level of respondents.

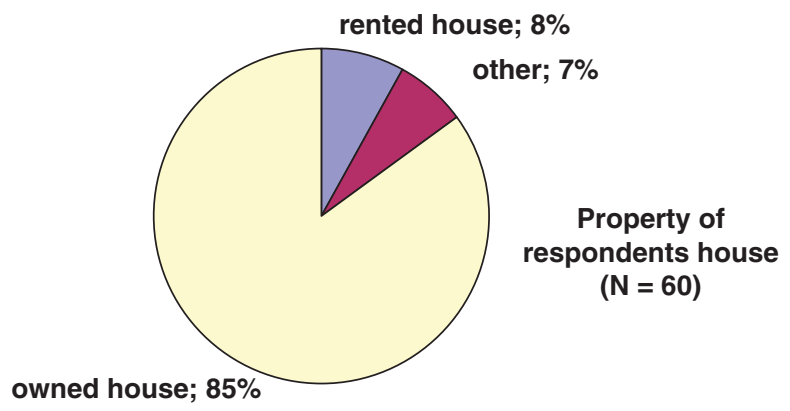

Figure 10 House ownership of respondents.
Regarding the three types of adaptation measures, protection, accommodation and retreat from the area, it appears that the second one, i.e. making adjustments to the land or house in order to stay, is the most popular. Protection measures such as building a seawall have to date not been executed by the respondents, as they assume this should be carried out by the government. For now, they do not prefer to move to other safer areas, because they are still able to cope with the effects of tidal flooding to their houses.

An interfering factor here is that the inhabitants of the inundated areas in many cases have been partly compensated by the government for adaptation costs. Besides, the government executes several projects to cope with the flood problems. Table 3 shows the costs of adaptation by inhabitants, ranging from less than IDR $1000000(\leq € 65)$ to more than IDR $10000000(\geq € 600)$. Most of the respondents (40\%) spend IDR $5000000-I D R 10000000$ (€300-€600) on adaptation measures. Meanwhile, $2 \%$ of the respondents have spent more than IDR 10000000 ( $\geq € 600$ ) on adaptation measures. The adaptation costs are varied depending on the financial capacity and the damage that has been suffered. The total sum of compensation that has been given out by the government is not available.

Most of the respondents $(43 \%)$ have been applying adaptation responses only once in every 2 years. Besides adaptation measures to their own houses and yards, most of the inhabitants participate in adaptation measures in their neighbourhoods in order to indirectly protect their properties. Table 4 shows that $37 \%$ of the respondents have been elevating the street level around their houses. Some respondents have been doing more than one adaptation measure, while about $15 \%$ of the respondents have not taken any adaptation measure.

It has been observed that people living in the inundated areas are able to organize themselves to cope with the tidal

Table 2 Type of adaptation responses at household level

\begin{tabular}{|c|c|c|c|}
\hline No. & Type of responses & Number & $\%$ \\
\hline \multicolumn{4}{|c|}{ One measure } \\
\hline 1 & Elevate the house & 11 & 21 \\
\hline 2 & Raise the floor level & 11 & 21 \\
\hline 3 & Raise the yard level & 7 & 13 \\
\hline 4 & Build dam to prevent water & 4 & 8 \\
\hline \multicolumn{4}{|c|}{ Two measures } \\
\hline 5 & Elevate the house and raise the floor level & 6 & 11 \\
\hline 6 & Raise the floor level and raise the yard level & 4 & 8 \\
\hline 7 & Elevate the house and and build dam to prevent water & 2 & 4 \\
\hline 8 & Raise the yard level and build dam to prevent water & 2 & 4 \\
\hline \multicolumn{4}{|c|}{ Three measures } \\
\hline 9 & Elevate the house, raise the floor level and raise the yard level & 4 & 8 \\
\hline 10 & Elevate the house, raise the floor level and build dam & 1 & 2 \\
\hline \multirow[t]{2}{*}{11} & Elevate the house, raise the yard level and raise the yard level & 1 & 2 \\
\hline & Total & 53 & 100 \\
\hline
\end{tabular}


flood problems. They pay the adaptation measures partly by themselves and through the collection of money from the community.

As the city government is carrying out various measures to help in the area, it is interesting for policy makers to

Table 3 Adaptation costs

\begin{tabular}{llr}
\hline \multicolumn{1}{c}{ Adaptation costs in IDR } & Number & $\%$ \\
\hline Less than IDR 1 000 000 $(\leq € 65)$ & 17 & 32 \\
IDR 1 000 000-IDR 5000 000 (€66-€300) & 21 & 40 \\
IDR 5 000 000-IDR 10000 000 (€301-€600) & 13 & 24 \\
More than IDR 10 000 000 ( $\geq € 600)$ & 2 & 4 \\
Total & 53 & 100 \\
\hline
\end{tabular}

see whether these efforts are observed by the inhabitants. The majority of the respondents are aware of governmental adaptation measures in their areas. Table 5 shows that most of the respondents (35\%) had knowledge of the city government elevating the street level. However, about $27 \%$ of the respondents declare that the city government never carries out any adaptation measure in their area.

Most of the 60 respondents (47) indicate that they prefer to stay in their current location, although 13 intend to leave the area within 5 years. Table 3 shows the rationale behind their intended choices.

Not only were interviews held with the inhabitants from the inundated areas but interviews were also held with people from areas that are predicted to be inundated in the

Table 4 Adaptation measures in neighbourhood level

\begin{tabular}{|c|c|c|c|}
\hline No & Adaptation type & Number & $\%$ \\
\hline \multicolumn{4}{|c|}{ No measure } \\
\hline 1 & None & 9 & 15 \\
\hline \multicolumn{4}{|c|}{ One measure } \\
\hline 2 & Elevate street & 22 & 37 \\
\hline 3 & Improve drainage system & 5 & 8 \\
\hline 4 & Create dyke system & 4 & 7 \\
\hline 5 & Provide pumps & 4 & 7 \\
\hline \multicolumn{4}{|c|}{ Two measures } \\
\hline 7 & Elevate street and improve drainage system & 6 & 10 \\
\hline 8 & Elevate street and create dyke system & 1 & 2 \\
\hline 9 & Elevate street and provide pumps & 1 & 2 \\
\hline 10 & Improve drainage system and provide pumps & 5 & 8 \\
\hline \multicolumn{4}{|c|}{ Three measures } \\
\hline 11 & Elevate street, improve drainage system and provide pumps & 2 & 3 \\
\hline \multirow[t]{2}{*}{12} & Elevate street, create dyke system and provide pumps & 1 & 2 \\
\hline & Total & 60 & 100 \\
\hline
\end{tabular}

Table 5 Awareness of adaptation measures executed by the city government

\begin{tabular}{|c|c|c|c|}
\hline No & Adaptation type & Number & $\%$ \\
\hline \multicolumn{4}{|c|}{ No measure } \\
\hline 1 & Nothing & 16 & 27 \\
\hline \multicolumn{4}{|c|}{ One measure } \\
\hline 2 & Elevate street & 21 & 35 \\
\hline 3 & Improve drainage system & 1 & 2 \\
\hline 4 & Create dyke system & 2 & 3 \\
\hline 5 & Provide pumps & 5 & 8 \\
\hline 6 & Others & 1 & 2 \\
\hline \multicolumn{4}{|c|}{ Two measures } \\
\hline 7 & Elevate street and improve drainage system & 6 & 10 \\
\hline 8 & Elevate street and create dyke system & 1 & 2 \\
\hline 9 & Improve drainage system and provide pumps & 2 & 3 \\
\hline \multicolumn{4}{|c|}{ Three measures } \\
\hline 10 & Elevate street, improve drainage system and provide pumps & 1 & 2 \\
\hline 11 & Elevate street, create dyke system and provide pumps & 1 & 2 \\
\hline \multirow[t]{2}{*}{12} & No answer & 3 & 5 \\
\hline & Total & 60 & 100 \\
\hline
\end{tabular}


Table 6 Reasons for intention to stay or to leave the regularly inundated areas

\begin{tabular}{lll}
\hline No & Respondents & \multicolumn{1}{c}{ Reasons } \\
\hline 1. & Stay & Limited finances \\
& & Close to work place \\
& Owned inherited family house \\
& Owned property in the area \\
& & Expect to compensate flooding with more \\
& adaptation measures \\
& Avoid floods \\
& Safety \\
& Choice for rented house elsewhere \\
& High costs of flood prevention and protection \\
&
\end{tabular}

near future. According to Wibowo (2006) by the year 2015, there will be another five more districts influenced by tidal floods. This concerns an estimated surface of around 8527.78 ha, representing more than $20 \%$ of the Semarang municipality area. Following the current trends of population, it can be expected that more than 1 million inhabitants will be affected by 2015 .

In order to understand future developments, it is useful for policy makers to know how the inhabitants of these areas expect to deal with the future threats of flooding. We interviewed randomly 50 inhabitants, of which more than $90 \%$ were middle income, middle educated and the owner of a house in the area.

Around $70 \%$ of these respondents prefer to stay in their current houses instead of moving to another area if flooding shall happen. Even though the tidal flood has not yet occurred in their areas, respondents are already planning to make adaptation measures, which mostly include elevation of the house or raising the floor level. Other measures that are mentioned are raising the yard level or building a dam to prevent the water to come into their territory. Respondents are willing to carry out more of these adaptation measures in the future, especially when the flood threat is higher.

The inhabitants are willing to pay for adaptation measures. Figure 11 shows that the majority of inhabitants intend to pay considerable costs on adaptation measures. Most of the people (45 from 50) are also willing to participate in collective measures for the neighbourhood.

It appears that in the areas that are at risk of flooding, the majority of respondents are eager to work, with or without the government, on measures to minimize negative flood impact.

\section{Discussion and recommendations}

This study indicates that climate-change adaptation is a reality in Semarang coastal districts. Tidal floods due to the rise in sea levels and land subsidence are experienced periodically in the investigated six subdistricts and affect

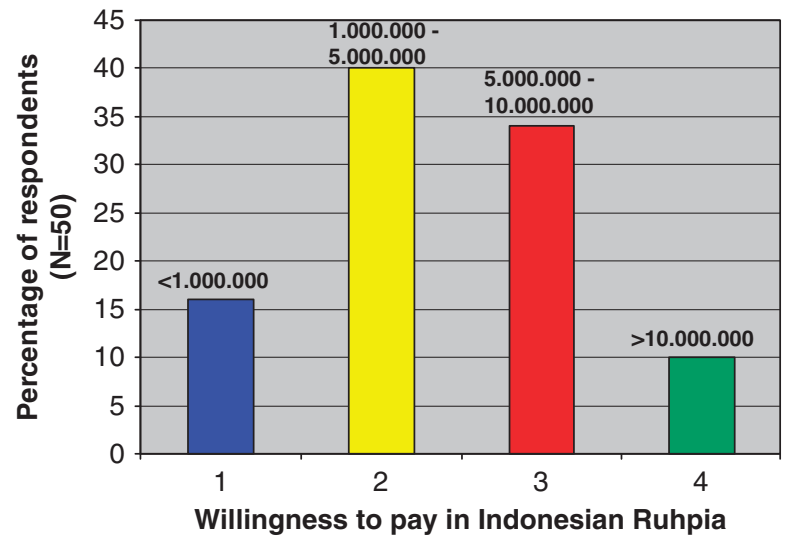

Figure 11 Willingness to pay by respondents.

the social, economical and environmental surrounding of the inhabitants. Until 2009, the houses of about 71395 people were inundated at least once by tidal flooding. Most of these houses are owned by middle-income and middleeducated households, that are presently performing, and for the future, are willing to perform adaptation measures.

Figure 12 shows the framework of adaptation responses in dealing with coastal flooding in settlement areas.

Inhabitants of areas that are under stress of tidal flooding prefer to take measures, both on their own and with the community or city government, to prevent tidal flooding of their property and their neighbourhood. In general, four types of physical adaptation measures by inhabitants and the city government can be identified:

- Autonomous adaptation measures, totally performed by the inhabitants in inundated areas, without any interventions from the city government.

- Autonomous adaptation measures on the neighbourhood level, performed and initiated by the inhabitants, but financed by the city government.

- Planned adaptation measures, performed by the city government based on initiatives from the inhabitants in the inundated areas.

- Planned adaptation measures performed and initiated by the city government. Communities are sometimes involved in the maintenance and operation of the flood protection infrastructures.

The measures usually occur as a reaction to the impact of tidal flooding; they are examples of reactive adaptation. However as far as future impacts are concerned, the intention to execute proactive adaptation measures can also be found. This anticipation is not elaborated into a processoriented approach that easily can adapt to all foreseen future developments. Here, the influence of government and policy are recommended to be extended. 


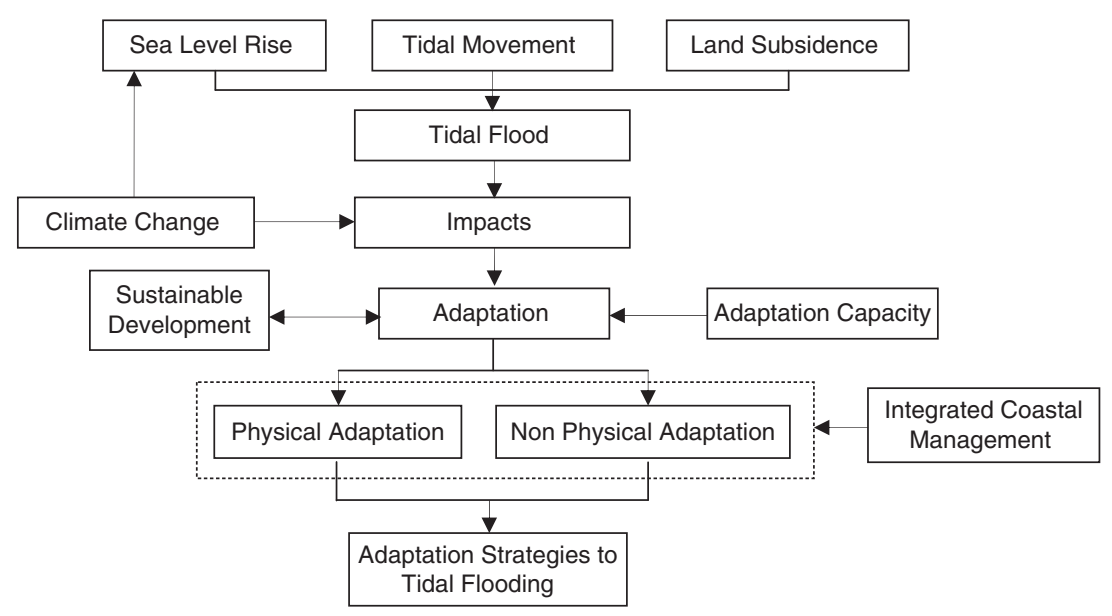

Figure 12 Framework of adaptation strategies.

From the physical measures that are executed, land elevation is the most common. Abandoning the area has not been greatly observed. As far as the activities of the government are concerned, there is no indication that one of the measures has priority; all of them are supported.

On the basis of the high level of initiatives from the private sector, i.e. the inhabitants themselves, the measures in dealing with tidal flood in Semarang mainly can be classified as autonomous adaptation.

Inhabitants of both present and predicted inundated areas are prepared to continue their activities in order to cope with the risks of future tidal flooding. They assess the possible adaptation options and are willing to pay adaptation costs. They have also indicated that they are willing to contribute towards collective adaptation measures in their neighbourhoods.

Several recommendations can be made for enhancing the adaptive capacity of the city government and the people that have to cope with the present and increasing tidal floods. By implementing the participation of the community, the city government can achieve and increase the effectiveness of their actions to adapt to tidal flooding. In order to improve flood management in the areas, the positive attitude towards collective measures, which is found among the inhabitants, is recommended to be utilized by the authorities.

This underpins the conclusion of Munasinghe and Swart (2005) that successful adaptation should involve every level of the government and of stakeholder groups. It is therefore recommended to integrate all relevant actors in the planning procedure of flood management. This implies citizens and other organizations from the private sector. By interaction with the inhabitants, it should be possible to stimulate collective adaptation strategies. Such a dialogue with society can be seen in approaches such as Integrated Coastal Management (ICM) (Post and Lundin, 1996; Harvey and Hilton, 2006). ICM has become a policy tool that engages a comprehensive framework from stakeholders at all levels of society that addresses multiple management issues (Mimura, 2006). Cummins et al. (2009) state that 'ICM is a dynamic and continuous process of administering the use, development and protection of the coastal zone and its resources towards common objectives of national and local authorities and the aspiration of different resource user groups'.

The main objective of ICM is sustainable development, translated in the projects and programmes directed at improvement of the biophysical environment and the quality of life of the coastal inhabitants (Olsen, 2003). It follows approaches such as interactive water management, involving both participation of societal actors and a dialogue with the ecosystem (Van Ast, 1999). Dealing with tidal flood does not only mean flood infrastructure development, but it is primarily an adaptation development process. This requires information about the trends within the water system and the society that has to deal with it. It also includes financial schemes to fund flood infrastructures and victim compensation. Especially, the most vulnerable should be taken into account, as the low-income and low-educated inhabitants are the ones renting houses, which suffer the most and are unable to take the necessary measures.

There are other questions that should be addressed such as what will happen when the sea levels continue to rise? Then, unavoidably the last strategy comes into the picture: abandoning the area. It is recommended that politicians should construct a long-term perspective for considering a gradual de-urbanization of these areas.

\section{Acknowledgements}

The authors want to express their gratitude to IHS (Institute for Housing and Urban development Studies) of Erasmus 
University Rotterdam for making this research possible and Ms Sharon Welsh for editing the language.

\section{References}

Adger W.N., Agrawala S., Mirza M.M.Q., Conde C., O’Brien K., Pulhin J., Pulwarty R., Smit B. \& Takahashi K. Assessment of adaptation practices, options, constraints and capacity. In: M.L. Parry, O.F. Canziani, J.P. Palutikof, P.J. van der Linden \& C.E. Hanson, eds. Climate change 2007: impacts, adaptation and vulnerability. Contribution of working group II to the fourth assessment report of the intergovernmental panel on climate change. Cambridge, UK: Cambridge University Press, 2007, 717-743.

Cummins V.O., Mahony C. \& Connolly N. 2009, Review of integrated coastal zone management \& principals of best practice. Available at http://www.heritagecouncil.ie (accessed 12 February 2010).

Dewi A., Community-based analysis of coping with urban flooding: a case study in Semarang, Indonesia. MSc Thesis, ITC, Enschede, the Netherlands, 2007.

Doornkamp J.C. Coastal flooding, global warming and environmental management. J Environ Manage 1998, 52, (4), 327-333.

Harvey N. \& Hilton M. Coastal management in the Asia-Pacific region. In N. Harvey, ed. Global change and integrated coastal management, coastal systems and continental margins, Volume 10. Dordrecht, the Netherlands: Springer, 2006, : 39-66.

Intergovernmental Panel on Climate Change (IPCC). Climate change 2007: synthesis report. Geneva, Switzerland: IPCC, 2007.

Japan International Cooperation Agency (JICA). Master plan on water resources development and feasibility study for urgent flood control and urban drainage in Semarang City and suburbs. Semarang, Indonesia: Public Works Department Semarang, 2003.

Klein R.J.T., Nicholls R.J., Ragoonaden S., Capoblanco M., Aston J. \& Buckly E.N. Technological options for adaptation to climate change in Coastal Zones. J Coast Res 2001, 17, (3), 531-543.

Marfai M.A. Spatial modelling of tidal flood hazard on East Semarang Coastal Area. J Forum Geografi, Indonesia 2004, 18, 60-69.

Marfai M.A. \& King L. Tidal inundation mapping under enhanced land subsidence in Semarang, Central Java Indonesia. Nat Hazards 2007a, 44, 93-109.

Marfai M.A. \& King L. Coastal flood management in Semarang, Indonesia. Environ Geol 2007b, 55, 1507-1518.

Marfai M.A., King L., Sartohadi J., Sudrajat S., Budiani S.R. \& Yulianto F. The impact of tidal flooding on a coastal community in Semarang, Indonesia. Environmentalist 2008, 28, 237-248.

McCarthy J., Canziani O.F., Leary N.A., Dokken D.J. \& White K.S. Climate change 2001: impacts, adaptation, and vulnerability.
IPCC working group II. Cambridge, UK: Cambridge University Press, 2001.

McGranahan G., Balk D. \& Anderson B. The rising tide: assessing the risks of climate change and human settlements in low elevation coastal zones. Environ Urban 2007, 19, (1), 17-37.

Mimura N. State of the environment in the Asia and Pacific coastal zone and effects of global change. In: N. Harvey, ed. Global change and integrated coastal management the Asia Pacific region. Dordrecht, the Netherlands: Springer, 2006, $17-35$.

Ministry of Fishery and Marine Affairs. Strategi Adaptasi Dan Mitigasi Bencana Pesisir Akibat Perubahan Iklim Terhadap Pesisir Dan Pulau-Pulau Kecil. Jakarta, Indonesia: Ministry of Fishery and Marine Affairs, 2009.

Munasinghe M. \& Swart R. Primer on climate change and sustainable development facts, policy analysis and applications. Cambridge UK: Cambridge University Press, 2005.

Nicholls R.J. Analysis of global impacts of sea level rise: a case study of flooding. Phys Chem Earth A/B/C 2002, 27, (32-34), 1455-1466.

Nicholls R.J. Coastal flooding and wetland loss in the $21^{\text {st }}$ century: changes under the SRES climate and socioeconomic scenarios. Glob Environ Change 2004, 14, (1), 69-86.

Nicholls R.J., Hoozemans F.M.J. \& Marchand M. Increasing flood risk and wetland losses due to global sea level rise: regional and global analysis. Glob Environ Change 1999, 9, (1), S69-S87.

Olsen S.B. Frameworks and indicators for assessing progress in integrated coastal management initiatives. Ocean \& coastal management 46, (3-4), 347-361.

Penning-Rowsell E. \& Peerbolte B. Concepts, policies and research. In: E. Penning-Rowsell \& M. Fordham, eds. Floods across Europe. Flood hazard assessment, modelling and management. London, UK: Middlesex University Press, 1994, $1-17$.

Pittock B. \& Jones R.N. Adaptation to what and why. Environ Monit Assess 2000, 61, 9-35.

Post J.C. \& Lundin C.G. (eds), Guidelines for integrated coastal zone management, environmentally sustainable development studies and monographs series, No 9. Washington DC, USA: World Bank, 1996.

Prasad N., Ranghieri F., Shah F., Trohanis Z., Kessler E. \& Sinha R. Climate resilient cities: a primer on reducing vulnerabilities to disaster. Washington, DC, USA: The World Bank, 2009.

Public Works Agency of Semarang (PWD). Semarang urban drainage master plan. Semarang, Indonesia: Public Work Department, 2000.

Satterthwaite D., Huq S., Reid H. \& Pelling L.P.R. Adapting to climate change in urban areas: the possibilities and constraints in low- and middle-income nations. In: J. Bicknell, D. Dodman \& D. Sattertwhaite, eds. Adapting cities to climate change; understanding and addressing the development challenges. London/Sterling, UK: Earthscan, 2007, 1-47.

Semarang Municipality. Maps of Semarang. Semarang, Indonesia: Semarang Municipality, 2009. 
Smit B. \& Pilifosofa O. Adaptation to climate change in the context of sustainable development and equity. In: McCarthy et al. eds. Climate change 2001, impacts, adaptation and vulnerability, international panel on climate change. Chapter 18 2001, 879-906.

Snoussi M., Ouchani T. \& Niazi S. Vulnerability assessment of the impact of sea-level rise and flooding on the Moroccan coast: the case of the Mediterranean eastern zone. J Estuar Coast Shelf Sci 2008, 77, (2), 206-213.

Statistic Bureau Indonesia. Statistics of Indonesia. Indonesia: Djakarta, 2010.

Statistic Bureau Semarang. Potensi Desa. Semarang Indonesia: Statistic Bureau, 2006.

Sutanta H., Rachman A. \& Sumaryo D., Predicting land use affected by land subsidence in semarang based on topographic map of scale 1:5000, 2005. Available at http:// www.gisdevelopment.net/application/natural_hazards/ overview/ma05118.htm (accessed 12 September 2009).

Syvitski J.P.M., Kettner A.J., Overeem I., Hutton E.W.H., Hannon M.T., Brakenridge G.R., Day J., Vörösmarty C., Saito Y., Giosan L. \& Nicholls R.J. Sinking deltas due to human activities. Nat Geosci 2009, 2, 681-686.

Van Ast J.A. Trends towards interactive water management; developments in international river basin management. Phys Chem Earth (B) 1999, 24, (6), 597-602.

Wibowo D.A., Spatial analysis of anxious tidal flood area at Semarang City. Thesis, Marine and Fisheries Faculty, Diponegoro University, Semarang, Indonesia, 2006. 


\section{Appendix A}

\section{Questionnaires addressed to respondents in present inundated areas}

Dear respondent,

I am conducting a study on adaptation responses of coastal settlements to coastal flooding in Semarang. The findings of this research will focus on the current and the year 2015 prediction effects of coastal flooding, adaptation responses of inhabitants who have been facing coastal flooding and who are predicted to be inundated and potential recommendations to local governments to deal with the coastal flooding problem. I therefore kindly ask for your time to respond to the flowing questions.

District

Sub District

Number of questionnaire.

Date

Characteristic of inhabitants

1. Profession

a. Fisherman

b. Farmer

c. Industrial labor

d. Government officer

e. Small business enterprise

f. Others

2. Income level
a. $\leq € 35$ ( $\leq$ Rp. 50000000$)$
b. €36-€100 (Rp. $50000000-R p .150000000$ )
c. $€ 101-€ 165$ (Rp. $150000000-$ Rp. 250000000$)$
d. $\geq € 166$ ( $\geq \operatorname{Rp} 250000000)$

3. Education level

a. Noneducated

b. Elementary school

c. High school

d. University

4. The house ownership
a. Own
b. Rent house
c. Others.

Flood condition

5. Has your house ever been inundated by coastal flooding?
a. Yes
b. No

6. How many years have you been suffering from coastal flooding?
a. Never
b. $\leq 3$ years
c. $4-8$ years
d. $\geq 8$ years

7. How many times in a month has your house been inundated?
a. $\leq 3$ times
b. 4-9 times
c. $\geq 10$ times
d. Every day 
8. How many centimeters is the most common flood depth?
a. $0-0.5$ meter
b. 0.51-1 meter
c. more than 1 meter

9. How many centimeters is the worst flood depth?
a. $0-0.5$ meter
b. 0.51-1 meter
c. more than 1 meter

10. How many hours takes the average time of the flood?
a. $<1$ hour
b. 1-24 hours
c. More than 1 day

11. How many hours was the worst flood?
a. $<1$ hour
b. 1-24 hours
c. More than 1 day

Impacts of coastal flooding

12. Have you or your family member ever suffered from illnesses due to coastal flooding?

a. Yes

b. No

13. If yes, what kind of illnesses have you suffered? (the answer can be more than one)
a. Diarrhea
b. Skin diseases
c. Dengue
d. Others

14. Do you have a child who is going to school?
a. Yes
b. No

15. If yes, how many days in a year could your child not go to school due to coastal flooding?
a. Never
b. $\leq 10$ days
c. 11-20 days
d. $\geq 21$ days

16. How many days in a year could you not go to work due to coastal flooding?
a. Never
b. $\leq 10$ days
c. 11-20 days
d. $\geq 21$ days

17. Did you lose income due to coastal flooding?
a. Yes
b. No

18. If yes, how much percent did you lose from your income in a year?
a. $<20 \%$
b. $21 \%-50 \%$
c. $>50 \%$

19. How do you get your drinking water?
a. Well
b. Water supply
c. Others

20. Does flooding affect your drinking water?
a. Yes
b. No 
21. If 'yes', what is the effect? (the answer can be more than one)
a. Color changed
b. Bad smell
c. Residue
d. Others

22. If yes, what did you do to get fresh water? (the answer can be more than one)
a. Nothing
b. Buy fresh water
c. Others

23. Does flooding affect your sanitation system?
a. Yes
b. No

24. If yes, what happens with your sanitation system? (the answer can be more than one)
a. The waste collector overflows
b. Bad smell
c. Others

Adaptation responses due to coastal flooding

25. Have you been doing adaptation measures in dealing coastal flooding?

a. yes

26. What kind of adaptation measures have you been doing so far to deal with coastal flooding? (the answer can be more than one)
a. Elevate the house
b. Raise the floor level
c. Raise the yard level
d. Build dam to prevent water
e. Others

27. How often have you been doing that measure?
a. Once in two years
b. Once in a year
c. More than once in a year
d. Others

28. How much did you pay for your adaptation measures mentioned in question 25 ?
a. $\leq € 65(<\operatorname{Rp} 100000000)$
b. €66-€300 (Rp $100000000-R p 500000000)$
c. $€ 301-€ 600$ (Rp 500000 100-Rp 1000000000$)$
d. $>€ 600$ ( > Rp 1000000000 )

29. What kind of adaptation measures has your community been doing in your neighborhood? (the answer can be more than one)
a. Nothing
b. Elevate the street
c. Improve the drainage system in the neighborhood
d. Create a dyke system in neighborhood
e. Provide pumps
f. Others

30. Do you think that adaptation measures can reduce the effects of coastal flooding effectively?
a. Yes
b. No

31. What kind of adaptation measures did government do in your neighborhood? (the answer can be more than one)
a. Nothing
b. Elevate the street
c. Improve the drainage system in the neighborhood 
d. Create a dyke system in the neighborhood

e. Provide pumps

f. Others

32. Do you think that adaptation measures done by governments can reduce the effects of coastal flooding effectively?

a. Yes

b. No

33. What do you prefer governments should do to deal with coastal flooding in your neighborhood?
a. Elevate the street
b. Improve the drainage system in the neighborhood
c. Create a dyke system in the neighborhood
d. Provide pumps
e. Others

34. Based on predictions for the year 2015 this area will be worse inundated, do you think the adaptation measures you have been doing can reduce these further effects effectively?

a. Yes

b. No

35. What will you do to deal with the worsened problem in the year 2015? (the answer can be more than one)
a. Elevate the house
b. Raise the floor level
c. Raise the yard level
d. Build dam to prevent water
e. Others

36. If your house is getting worse affected by coastal flooding, do you consider moving to another area that is not vulnerable to flooding?
a. Yes

b. No

37. Please give your reason for your answer

Thank you for your answer.

\section{Questionnaires addressed to respondents in predicted inundated areas}

Dear respondent,

I am conducting a study on adaptation responses of coastal settlements to coastal flooding in Semarang. The findings of this research will focus on the current and the year 2015 prediction effects of coastal flooding, adaptation responses of inhabitants who have been facing coastal flooding and who are predicted to be inundated and potential recommendations to local government to deal with the coastal flooding problem. I therefore kindly ask for your time to respond on the flowing questions.

District
Sub District
Number of questionnaire
Date

Characteristic of inhabitants

1. Profession

a. Fisherman

b. Farmer

c. Industrial labor 
d. Government officer

e. Small business enterprise

f. Others

2. Income level
a. $\leq € 35$ ( $\leq$ Rp. 50000000$)$
b. $€ 36-€ 100$ (Rp. 50000 100-Rp. 150000000 )
c. $€ 101-€ 165$ (Rp. 150000 100-Rp. 250000 000)
d. $\geq € 166$ ( $\geq \operatorname{Rp} 2500000100)$

3. Education level

e. Noneducated

f. Elementary school

g. High school

h. University

4. The house ownership
a. Own
b. Rent house
c. Others

Impacts of coastal flooding

5. Do you know about coastal flooding?

a. Yes

b. No

6. If yes, what do you know about coastal flooding in Semarang? (the answer can be more than one)

a. Flooding because of the rise in sea levels

b. Flooding because of land subsidence

c. Flooding because sea water intrude to land

d. Flooding which happen periodically because of lunar gravitation

e. Others

7. In your opinion, will your house be inundated in the next five years?
a. Yes

b. No

8. In your opinion, what will be the loss if there is coastal flooding in your neighborhood? (the answer can be more than one)
a. Damage houses and building
b. Decrease income
c. Cannot got to work
d. Children cannot go to school
e. Decrease health quality
f. Decrease environment quality
g. Decrease drinking water quality
h. Others

Adaptation responses

9. It is predicted that in year 2015 your neighborhood will be inundated by coastal flooding. What will you do to deal with this problem?

a. Stay

b. Move to another area

10. Please give your reason of your choice of question 9 ?.

11. In your opinion, when is the proper time to do adaptation responses to deal with coastal flooding?

a. Start from now

b. Immediately when your neighborhood starts to be inundated 
12. What adaptation respond will you do in dealing with coastal flooding? (the answer can be more than one)
(a). Elevate the house
(b). Raise the floor level
(c). Raise the yard level
(d). Build dam to prevent water
(e). Others

13. How much do you want to spend for doing your adaptation measures mentioned in question 12 ?
(a). $\leq € 65(<\operatorname{Rp} 100000000)$
(b). €66-€300 (Rp $100000000-R p 500000000)$
(c). €301-€600 (Rp 500000 100-Rp 1000000000$)$
(d). $>€ 600$ ( > Rp 1000000000 )

14. When is the proper time for governments to do adaptation responses?

a. Before the time that coastal flooding inundates your neighborhood

b. Immediately when your neighborhood started to be inundated

15. What kind of adaptation responses should be done by the government in dealing with coastal flooding in your neighborhood? (the answer can be more than one)

a. Socialization about coastal flooding

b. Elevate the street level

c. Improving the drainage system in the neighborhood

d. Creating a dyke system in the neighborhood

e. Provide pumps

f. Others

16. What kind of adaptation measures will your community do in your neighborhood to deal with coastal flooding? (the answer can be more than one)
a. Nothing
b. Elevate the street level
c. Improve the drainage system in the neighborhood
a. Create a dyke system in the neighborhood
b. Provide pumps
Others

17. In your opinion, who is the most responsible actor in dealing with coastal flooding in your neighborhood?
a. Government
b. Community
c. Government and the community

Thank you for your answer. 